\title{
Ozone variability and halogen oxidation within the Arctic and sub-Arctic springtime boundary layer
}

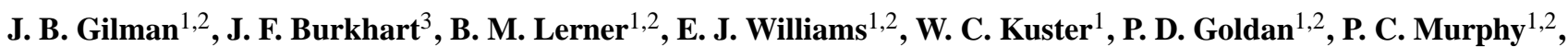 \\ C. Warneke ${ }^{1,2}$, C. Fowler ${ }^{4}$, S. A. Montzka ${ }^{1}$, B. R. Miller ${ }^{1,2}$, L. Miller ${ }^{1,2}$, S. J. Oltmans ${ }^{1}$, T. B. Ryerson ${ }^{1}$, \\ O. R. Cooper ${ }^{1,2}$, A. Stohl ${ }^{3}$, and J. A. de Gouw ${ }^{1,2}$ \\ ${ }^{1}$ Earth System Research Laboratory (ESRL), NOAA, Boulder, CO, USA \\ ${ }^{2}$ Cooperative Institute for Research in the Environmental Sciences (CIRES), University of Colorado, Boulder, CO, USA \\ ${ }^{3}$ Norwegian Institute for Air Research (NILU), Kjeller, Norway \\ ${ }^{4}$ Colorado Center for Astrodynamics Research (CCAR), University of Colorado, Boulder, CO, USA
}

Received: 6 May 2010 - Published in Atmos. Chem. Phys. Discuss.: 29 June 2010

Revised: 7 October 2010 - Accepted: 19 October 2010 - Published: 2 November 2010

\begin{abstract}
The influence of halogen oxidation on the variabilities of ozone $\left(\mathrm{O}_{3}\right)$ and volatile organic compounds (VOCs) within the Arctic and sub-Arctic atmospheric boundary layer was investigated using field measurements from multiple campaigns conducted in March and April 2008 as part of the POLARCAT project. For the ship-based measurements, a high degree of correlation $(r=0.98$ for 544 data points collected north of $68^{\circ} \mathrm{N}$ ) was observed between the acetylene to benzene ratio, used as a marker for chlorine and bromine oxidation, and $\mathrm{O}_{3}$ signifying the vast influence of halogen oxidation throughout the ice-free regions of the North Atlantic. Concurrent airborne and ground-based measurements in the Alaskan Arctic substantiated this correlation and were used to demonstrate that halogen oxidation influenced $\mathrm{O}_{3}$ variability throughout the Arctic boundary layer during these springtime studies. Measurements aboard the R/V Knorr in the North Atlantic and Arctic Oceans provided a unique view of the transport of $\mathrm{O}_{3}$-poor air masses from the Arctic Basin to latitudes as far south as $52^{\circ} \mathrm{N}$. FLEXPART, a Lagrangian transport model, was used to quantitatively determine the exposure of air masses encountered by the ship to first-year ice (FYI), multi-year ice (MYI), and total ICE (FYI+MYI). $\mathrm{O}_{3}$ anti-correlated with the modeled total ICE tracer $(r=-0.86)$ indicating that up to $73 \%$ of the $\mathrm{O}_{3}$ variability measured in the Arctic marine boundary layer could be related to sea ice exposure.
\end{abstract}

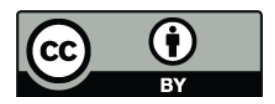

Correspondence to: J. Gilman (jessica.gilman@noaa.gov)

\section{Introduction}

Long-term measurements of surface ozone $\left(\mathrm{O}_{3}\right)$ in the Arctic have shown that the greatest interannual variability occurs in the late winter and spring (Oltmans and Komhyr, 1986). During the Arctic springtime, surface $\mathrm{O}_{3}$ can fluctuate between background levels of approximately $40 \mathrm{ppbv}$ to near zero. While major ozone depletion events (ODEs, $\mathrm{O}_{3}<4 \mathrm{ppbv}$ ) are episodic in nature, they have been shown to occur perennially in the Arctic springtime boundary layer across the whole of the Arctic Basin (Oltmans and Komhyr, 1986; Bottenheim et al., 1990; Sturges et al., 1993; Solberg et al., 1996; Hopper et al., 1998; Ridley et al., 2003; Bottenheim et al., 2009; Hirdman et al., 2010). Air masses depleted in $\mathrm{O}_{3}$ can remain so for several days due to the relatively stable and stratified nature of the Arctic boundary layer (Barrie and Platt, 1997; Stohl, 2006), which limits mixing with surrounding air masses. The most efficient way for an Arctic air mass depleted in $\mathrm{O}_{3}$ to replenish itself is by mixing with $\mathrm{O}_{3}$-rich air since photochemical $\mathrm{O}_{3}$ production is generally not sufficient (Simpson et al., 2007b).

Observed $\mathrm{O}_{3}$ depletions in the Arctic springtime boundary layer have been associated with air masses that were exposed to significantly enhanced concentrations of halogen atoms including atomic bromine $(\mathrm{Br})$ and chlorine $(\mathrm{Cl})$ radicals (Barrie et al., 1988; Oltmans et al., 1989; Jobson et al., 1994). It has been posited that $\mathrm{Br}$ is responsible for the near complete destruction of surface $\mathrm{O}_{3}$ on the timescale of about a day by a photochemical, catalytic, chain-reaction; however, the mechanism in which the reactive halogens are liberated from the Arctic Ocean where they exist as inert halide salts

Published by Copernicus Publications on behalf of the European Geosciences Union. 
is not entirely clear (Barrie et al., 1988; McConnell et al., 1992; Simpson et al., 2007b). Even though chlorine is the most abundant halide in seawater, the abundance of reactive $\mathrm{Br}$ atoms has been shown to exceed that of $\mathrm{Cl}$ by factors of $10^{2}-10^{3}$ during ODEs (Jobson et al., 1994; Cavender et al., 2008). While $\mathrm{Cl}$ may not contribute much to $\mathrm{O}_{3}$ destruction, $\mathrm{Cl}$ rapidly oxidizes a wide range of volatile organic compounds (VOCs) including alkanes, alkenes, and acetylene. Jobson et al. (1994) showed that the coincidental loss of a series of $n$-alkanes during ODEs could be readily explained by $\mathrm{Cl}$ oxidation kinetics. Acetylene was the only hydrocarbon that showed more decay than could be explained by $\mathrm{Cl}$ chemistry alone. $\mathrm{Br}$ oxidation was invoked in order to fully account for the loss of acetylene in $\mathrm{O}_{3}$ depleted air masses. These observations directly link surface $\mathrm{O}_{3}$ destruction and the oxidation of VOCs to the reactive halogens $\mathrm{Cl}$ and $\mathrm{Br}$.

Previous studies have utilized modeled air mass back trajectories in order to identify possible source regions of $\mathrm{O}_{3}$ depletion chemistry. These studies showed that air masses depleted in $\mathrm{O}_{3}$ had advected over the predominately ice- and snow-covered Arctic Ocean (Hopper et al., 1998) or over open leads in the sea ice (Sturges et al., 1993). Arctic sea ice can be divided into two main categories: multi-year ice (MYI) and first-year ice (FYI). MYI has survived the annual melt, which typically peaks in September in the Arctic, whereas FYI is formed subsequent to the annual melt. While FYI can eventually evolve into MYI, the two types of ice differ geographically, chemically, and physically. MYI is located primarily in the western Arctic near Greenland and the Canadian archipelago while FYI forms in the eastern (Siberian) Arctic and is transported westward across the pole (Fowler et al., 2004; Belchansky et al., 2005). FYI has been shown to have a higher salinity than MYI particularly during the initial freezing process, which forms a concentrated brine layer at the surface (Notz and Worster, 2008). Additionally, open leads and polynyas, semi-permanent areas of open water surrounded by sea ice, are often associated with areas of FYI because it is thinner and more susceptible to fragmentation by the wind and ocean currents. Open leads and polynyas can be a direct source of sea-salt aerosols or they can be covered by a thin layer of ice allowing for the growth of saline crystals called frost flowers (Martin et al., 1995; Kaleschke et al., 2004). While young sea ice has been implicated in halogen activation and $\mathrm{O}_{3}$ depletion (Wagner et al., 2001; Simpson et al., 2007a; Bottenheim et al., 2009), MYI has not generally been considered to be a strong source of the reactants required for $\mathrm{O}_{3}$ destruction chemistry.

A series of concurrent field observations from multiple platforms were conducted in spring 2008 as part of POLARCAT (Polar Study using Aircraft, Remote Sensing, Surface Measurements and Models, of Climate, Chemistry, Aerosols, and Transport, http://www.polarcat.no/), which was a large international program organized as part of the 2007-2008 International Polar Year. In this work, results from (1) ICEALOT (International Chemistry Experiment in the Arctic
Lower Troposphere), a ship-based study in the North Atlantic and Arctic Oceans aimed at characterizing the atmospheric composition of the ice- and snow-free regions of the Arctic, (2) ARCPAC (Aerosol, Radiation, and Cloud Processes affecting Arctic Climate), an airborne study over northern Alaska and the frozen Beaufort Sea, and (3) ground-based measurements at Barrow, Alaska, are used to investigate the influence of halogen oxidation on $\mathrm{O}_{3}$ variability within the Arctic and sub-Arctic. Data from two mid-latitude studies on the Atlantic and Pacific coasts (2004 New England Air Quality Study and Trinidad Head, CA, respectively) are compared to the Arctic datasets in order to investigate the broader, spatial-scale variations in $\mathrm{O}_{3}$. Lastly, FLEXPART, a Lagrangian particle dispersion model (Stohl et al., 2002, 2005), was used to quantitatively determine the exposure of air masses sampled during ICEALOT to FYI, MYI, and total ICE (FYI+MYI) in order to determine if the variability in $\mathrm{O}_{3}$ could be explained by the exposure to specific types of sea ice.

\section{Experimental}

\subsection{Ship-based measurements in North Atlantic and Arctic Oceans}

The International Chemistry Experiment in the Arctic Lower Troposphere (ICEALOT) was conducted aboard the R/V Knorr in the North Atlantic and Arctic Oceans in March and April 2008 as part of the larger POLARCAT program. The cruise track of the R/V Knorr, operated by Woods Hole Oceanographic Institution, is shown in Fig. 1 and has been colored by measured $\mathrm{O}_{3}$ mixing ratios. The cruise has been divided into four areas of study which include the northeastern United States (NE US, $41^{\circ} \mathrm{N}$ to $45^{\circ} \mathrm{N}$ ), the sub-Arctic $\left(45^{\circ} \mathrm{N}\right.$ to $68^{\circ} \mathrm{N}$ excluding Iceland leg of cruise), the Arctic $\left(68^{\circ} \mathrm{N}\right.$ to $80^{\circ} \mathrm{N}$ ), and Iceland (IS, $62^{\circ} \mathrm{N}$ to $\left.68^{\circ} \mathrm{N}\right)$.

A full suite of volatile organic compounds (VOCs), including C2-C6 hydrocarbons, C2-C4 oxygenated VOCs, C6-C9 aromatics, halogenated VOCs, alkyl nitrates, dimethyl sulfide (DMS), and acetonitrile, were measured in situ by a custom built, two-channel, gas chromatograph-mass spectrometer (GC-MS). The inlet for the GC-MS consisted of a $30 \mathrm{~m}$ unheated Teflon line, which was positioned on the forward mast of the R/V Knorr approximately $25 \mathrm{~m}$ above the waterline. Ambient air was pulled continuously at a rate of approximately $7 \mathrm{~L} \mathrm{~min}^{-1}$ through the inlet line resulting in an inlet residence time of approximately $3 \mathrm{~s}$. From this highflow sample stream, two separate ambient air samples were collected simultaneously at a flow rate of $70 \mathrm{sccm}$ for a total of $5 \mathrm{~min}$ via cryogenic trapping. The two sample channels have slightly different configurations designed to reduce water and carbon dioxide and remove $\mathrm{O}_{3}$ from the sample stream prior to trapping as described in Goldan et al. (2004). After the $5 \mathrm{~min}$ sample acquisition period, the two samples 
Table 1. Summary of the measurement parameters, statistics, and reaction rate coefficients for $\mathrm{OH}\left(k_{\mathrm{OH}}\right), \mathrm{Cl}\left(k_{\mathrm{Cl}}\right)$, and $\mathrm{Br}\left(k_{\mathrm{Br}}\right)$ with a select group of VOCs measured during ICEALOT. The mean, median, maximum, and minimum values are for the 891 VOC samples in the sub-Arctic and Arctic.

\begin{tabular}{|c|c|c|c|c|c|c|c|c|c|c|}
\hline Compound & LOD & Precision & Accuracy & Mean & Median & Max & Min & $\mathrm{kOH}$ at $250 \mathrm{~K}$ & $\mathrm{kCl}$ at $250 \mathrm{~K}$ & $\mathrm{kBr}$ at $250 \mathrm{~K}$ \\
\hline Ethane & 0.0100 & $8 \%$ & $15 \%$ & 1.694 & 1.731 & 2.145 & 0.976 & $0.12[\mathrm{~A}]$ & $55.6[\mathrm{~A}]$ & NR \\
\hline i-Butane & 0.0050 & $5 \%$ & $15 \%$ & 0.106 & 0.100 & 0.309 & 0.028 & $1.71[\mathrm{~B}]$ & $137\left[\mathrm{~F}^{*}\right]$ & NR \\
\hline n-Butane & 0.0050 & $5 \%$ & $15 \%$ & 0.182 & 0.190 & 0.941 & 0.027 & $1.78[\mathrm{~B}]$ & $198\left[\mathrm{~F}^{*}\right]$ & NR \\
\hline i-Pentane & 0.0010 & $5 \%$ & $20 \%$ & 0.056 & 0.058 & 0.392 & 0.008 & $3.60\left[\mathrm{~B}^{*}\right]$ & $203\left[\mathrm{~F}^{*}\right]$ & NR \\
\hline Acetylene & 0.0100 & $10 \%$ & $20 \%$ & 0.365 & 0.376 & 0.562 & 0.071 & $0.78\left[\mathrm{C}^{*}\right]$ & $71\left[\mathrm{G}^{*}\right]$ & $0.154\left[\mathrm{~K}^{*}\right]$ \\
\hline Benzene & 0.0005 & $3 \%$ & $20 \%$ & 0.097 & 0.099 & 0.127 & 0.054 & $0.91[\mathrm{C}]$ & $4.0\left[\mathrm{G}^{*}\right]$ & NR \\
\hline Acetaldehyde & 0.0010 & $15 \%$ & $25 \%$ & 0.065 & 0.056 & 0.334 & 0.004 & $19.1[\mathrm{~A}]$ & $72[\mathrm{~A}]$ & 3.08 [L] \\
\hline Propanal & 0.0010 & $15 \%$ & $25 \%$ & 0.029 & 0.023 & 0.189 & 0.005 & $25.8[\mathrm{~A}]$ & $120\left[\mathrm{~A}^{*}\right]$ & $9.73[\mathrm{~L} *]$ \\
\hline Butanal & 0.0010 & $15 \%$ & $25 \%$ & 0.013 & 0.009 & 0.130 & 0.002 & $30.9[\mathrm{~A}]$ & $137\left[\mathrm{H}^{*}\right]$ & $20[\mathrm{M}]$ \\
\hline Acetone & 0.0100 & $15 \%$ & $25 \%$ & 0.476 & 0.473 & 0.962 & 0.158 & 0.14 [D] & $1.42[\mathrm{I}]$ & NR \\
\hline
\end{tabular}

LOD = Limit of detection; Precision = Reproducibility; Italic $=$ Associated with Kola Peninsula plume sampled on 8 April 2008 ; Bold $=$ Associated with ozone depletion event sampled 15-20 April 2008; [A] = Atkinson et al. (2001); [B] = Atkinson et al. (2003); [C] = Atkinson (1986); [D] = Wallington and Kurylo (1987); [E] = DeMore et al. (1997); [F] = Atkinson and Aschmann (1985); [G] = Wallington et al. (1988); [H] = Cuevas et al. (2006); [I] = Zhao et al. (2008); [J] = Kamboures et al. (2002); [K] = Barnes et al. (1993); [L] = Wallington et al. (1989); [M] = Ramancher et al. (2000) NR = Negligible Reactivity; * denotes rate coefficients at $298 \mathrm{~K}$

are transferred to cryofocus units positioned at the heads of the two GC columns. Channel one (CH1) consists of an $18 \mathrm{~m}$ $\mathrm{Al}_{2} \mathrm{O}_{3} / \mathrm{KCl}$ PLOT column, and the second channel $(\mathrm{CH} 2)$ utilizes a semi-polar $20 \mathrm{~m}$ DB-624 capillary column. After the sample transfer is complete, the cryofocus unit on $\mathrm{CH} 1$ is then flash heated from $-165^{\circ} \mathrm{C}$ to $100^{\circ} \mathrm{C}$ in $0.2 \mathrm{~s}$ injecting the sample onto the $\mathrm{CH} 1$ column for subsequent analysis by a linear quadrupole mass spectrometer (Agilent 5973). While the $\mathrm{CH} 1$ sample is being analyzed, the $\mathrm{CH} 2$ sample is held in its cryofocus unit for an additional 192 seconds. When the analysis of the $\mathrm{CH} 1$ sample is near completion, the cryofocus unit on $\mathrm{CH} 2$ is flash heated injecting the sample onto the $\mathrm{CH} 2$ column. Immediately after injection, a 4-way pneumatic valve (Valco Instruments Co. Inc., Houston, TX) located upstream of the mass spectrometer switches so that the sample eluting from the $\mathrm{CH} 2$ column is now directed to the detector while the remaining $\mathrm{CH} 1$ carrier gas is vented. The entire sample collection ( $5 \mathrm{~min}$ ) and analysis sequence ( $25 \mathrm{~min}$ ) repeats automatically every $30 \mathrm{~min}$ beginning on the hour and half-hour. The detection limits and uncertainties of the VOC measurements detailed this study are compiled in Table 1. The gas-phase data have been filtered for contamination by the ship itself.

$\mathrm{O}_{3}$ was measured via UV absorbance by a commercial instrument (Thermo Environmental Instruments, Inc., Model 49c). Carbon monoxide (CO) was measured by a vacuumUV resonance fluorescence instrument (Gerbig et al., 1999). The $\mathrm{O}_{3}$ and $\mathrm{CO}$ measurements presented in this analysis rep- resent 5 minute averages coincident with the GC-MS sample acquisition. Radon measurements, detailed in Bates et al. (2008), are $30 \mathrm{~min}$ averages which overlap with each of the GC-MS samples.

\subsection{Airborne measurements in Alaskan Arctic}

The Aerosol, Radiation, and Cloud Processes affecting Arctic Climate (ARCPAC) study, which was part of the larger POLARCAT program, was conducted in Fairbanks, Alaska, in April 2008 using the NOAA WP-3D aircraft. NOAA whole air samples (NWAS) were collected in glass flasks during the research flights that were made over northern Alaska and the frozen Beaufort Sea. The flasks were transported to the NOAA Global Monitoring Division laboratory in Boulder, Colorado, where they were analyzed within a few days for hydrocarbons and halocarbons using GC-MS (Montzka et al., 1993; Warneke et al., 2009). The limit of detection for the VOCs in the NWAS is approximately $5 \mathrm{ppt}$. The NWAS acetylene results have been multiplied by a factor of 1.3 so that the acetylene measurements were on a consistent scale with the shipboard in situ GC-MS. The factor of 1.3 is based on measured differences in the calibration standards of acetylene used by the different research groups. We have not attempted to resolve here which standards are more accurate.

During ARCPAC, $\mathrm{O}_{3}$ was measured with a 50 pptv limit of detection and $4 \%$ uncertainty on a 1-s time base using NO-induced chemiluminescence (Ryerson et al., 1998). $\mathrm{O}_{3}$ 


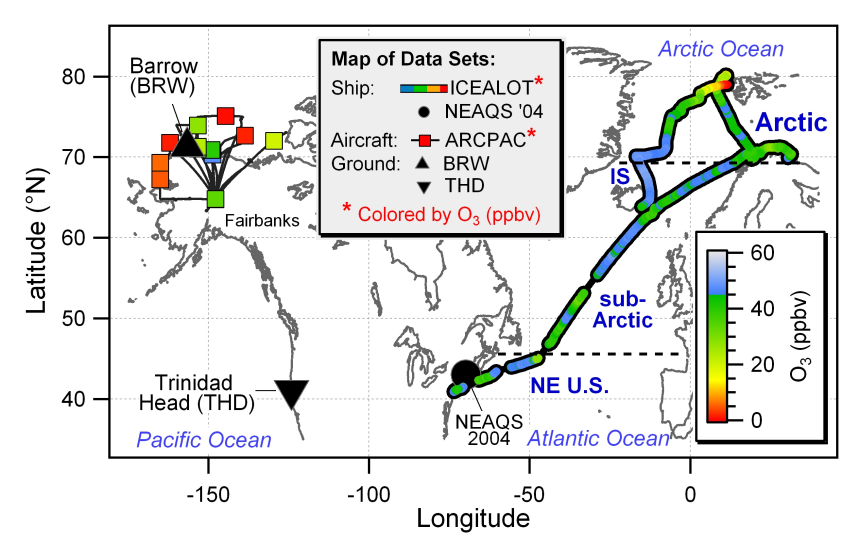

Fig. 1. Locations of the data sets used in this analysis. The four data subsets of the ICEALOT campaign aboard the R/V Knorr, which include the northeastern United States (NE US), sub-Arctic, Arctic, and Iceland (IS), are identified. The ICEALOT ship track and the flask samples collected along the ARCPAC flight tracks in Northern Alaska are colored by measured $\mathrm{O}_{3}$ mixing ratios. Additional data sets include flask samples collected at ground-based observatories in Barrow, Alaska, (BRW) and Trinidad Head, California, (THD) as well as ship-based studies from the 2004 New England Air Quality Study (NEAQS '04) aboard the R/V Brown.

mixing ratios were averaged over the NWAS collection time, which ranged from 6 to $15 \mathrm{~s}$ depending on altitude. In the analysis presented here, only the measurements of acetylene and benzene in the 14 NWAS that were collected below $1 \mathrm{~km}$ in altitude and had mean CO mixing ratios of less than 190 ppbv are included. Samples with mean CO $>190$ ppbv have been excluded from this analysis as these samples are considered to be significantly above the Arctic springtime background of $160 \mathrm{ppbv}$ (Warneke et al., 2009) due to contributions from biomass burning. Figure 1 shows the flight tracks and sampling locations of each of the NWAS, which have been colored by their respective mean $\mathrm{O}_{3}$ mixing ratios.

\subsection{Ground-based measurements in Barrow, $\mathrm{AK}$ and Trinidad Head, CA}

The Barrow, Alaska, Observatory (BRW at $71.32^{\circ} \mathrm{N}$, $156.61^{\circ} \mathrm{W}$ ) is located approximately $8 \mathrm{~m}$ above sea level near the northernmost point of the United States. The prevailing winds at BRW are from the east-northeast off the Beaufort Sea (Oltmans and Levy, 1994). The Observatory at Trinidad Head, California, (THD at $41.05^{\circ} \mathrm{N}, 124.15^{\circ} \mathrm{W}$ ) is located on the northern coast of California about $100 \mathrm{~m}$ above sea level. THD is a relatively remote, mid-latitude, coastal site with prevailing maritime airflow off the Pacific Ocean (Oltmans et al., 2008). NOAA whole air samples are collected in stainless steel canisters at both surface sites on a weekly basis year round, but only a subset of those flasks are analyzed for acetylene on the same instrument and by the same procedures as described in Sect. 2.2.
$\mathrm{O}_{3}$ is measured by UV absorption at both surface sites year round (Oltmans and Levy, 1994). The $\mathrm{O}_{3}$ measurements presented here are hourly averages encompassing the time that each flask was filled. The data collected at the surface sites during January through May of 2008 and January to February of 2009 are included in this analysis. This dataset represents the entire acetylene record at both sites for winter and spring that was available at the time of this analysis.

\subsection{FLEXPART model description}

FLEXPART, a Lagrangian particle dispersion model, has been extensively validated (Stohl et al., 1998, 2003) and has been used to investigate long-range transport to the Arctic (Stohl, 2006; Warneke et al., 2009, 2010; Hirdman et al., 2010). The FLEXPART model differs from traditional isentropic back trajectories in that thousands of particles are released and subjected to atmospheric dynamics including mean wind fields, convection, and turbulence (Stohl et al., 2002, 2003, 2005, see also http://transport.nilu.no/flexpart). For this analysis, each release consisted of 60000 particles. Releases occurred every $30 \mathrm{~min}$, or sooner if there was a shift in wind direction greater than $15^{\circ}$ or if the ship moved more than $0.18^{\circ}$ in latitude or longitude, for a total of 1,735 releases along the cruise track. The paths of the particles in each release were then tracked for 20 days back in time using the mean winds interpolated from the European Center for Medium-Range Weather Forecasts (ECMWF) operational analyses with $0.5^{\circ} \times 0.5^{\circ}$ resolution. The wind fields were updated every three hours beginning at midnight UTC.

The backward simulations of the paths of the particles were mapped onto a uniform 3-dimensional grid as a function of time since the release. From the particle locations, FLEXPART provides a Potential Emission Sensitivity (PES) function, a so-called source-receptor-relationship (Seibert and Frank, 2004). The PES value (in units of $\mathrm{s} \mathrm{kg}^{-1}$ ) in a particular grid cell is proportional to the residence time of the particle in that grid cell (Hirdman et al., 2010). This analysis utilizes the PES value for the footprint layer, which is defined in the model as the lowest $100 \mathrm{~m}$ of the atmosphere. All particles that reside within this shallow layer are presumed to be in contact with Earth's surface. While the generally stratified nature of the Arctic boundary layer can lead to gradients within this $100 \mathrm{~m}$ layer, field measurements in the Arctic aboard the R/V Knorr (Lerner et al., 2010) and NOAA WP-3D (Neuman et al., 2010) indicate that the atmospheric boundary layer depth was no less than $150 \mathrm{~m}$ when air masses with depleted $\mathrm{O}_{3}$ were observed.

The PES values $\left(\mathrm{skg}^{-1}\right)$ for the footprint layer were then folded with gridded "sea ice emission fluxes" (units of $\mathrm{kg} \mathrm{s}^{-1} \mathrm{~m}^{-2}$ ). In this application of FLEXPART, the modeled emission is of an inert "FYI or MYI tracer." This is analogous to the FLEXPART modeling of an atmospheric tracer such as $\mathrm{CO}$ at a receptor site based on emission fluxes of CO from a gridded emission inventory (Stohl et al., 2003). 
First-year ice (FYI) or multi-year ice (MYI) within a particular grid cell is assigned an arbitrary unit emission of $1.0 \mathrm{~kg} \mathrm{~s}^{-1} \mathrm{~m}^{-2}$, while grids comprised of open water or land were assigned an emission of $0.0 \mathrm{~kg} \mathrm{~s}^{-1} \mathrm{~m}^{-2}$. The FYI or MYI tracers are assumed to be instantaneously mixed within the gridded footprint volume upon emission. The sea ice was classified as FYI or MYI by the procedures outlined in Fowler et al. (2004). The sea ice coverage maps and classifications were updated weekly. The result of folding the footprint PES values with the gridded FYI or MYI emission fluxes is a map of the sea ice source contribution (units of ppbv $\mathrm{m}^{-2}$ ), which depicts the magnitude and location of the particles' exposure to FYI or MYI tracer emissions.

By summing up all the FYI or MYI Source Contributions from each grid cell and integrating over the grid area (units of $\mathrm{m}^{2}$ ), the mixing ratio of the inert FYI or MYI tracers (in units of ppbv) can be determined for each release along the ship track for 1 to 20 days prior to the initial release. While the amount of the FYI and MYI tracers are quantitative, the absolute scale is arbitrary due to the fact that a unit emission factor of a fictitious tracer was used. The term "exposure" used throughout this text is defined here as the modeled quantity (ppbv) of the specified type of inert ice tracer, which is directly proportional to the time that an air mass was in contact with the specified types of sea ice. Examples of the various FLEXPART model outputs are further discussed in Sect. 3.4.

\section{Results and discussion}

\subsection{VOC ratios as oxidation markers}

Primary oxidants of VOCs in the Arctic springtime include the hydroxyl radical $(\mathrm{OH})$ and the halogen atoms $\mathrm{Br}$ and $\mathrm{Cl}$ (Jobson et al., 1994). These oxidants determine the chemical lifetimes of VOCs that are emitted or transported into the Arctic. The reactivities of VOCs with $\mathrm{OH}, \mathrm{Cl}$, and $\mathrm{Br}$ can be used to determine the relative importance of the different oxidants (Jobson et al., 1994; Ramacher et al., 1999; Cavender et al., 2008). For example, the propane to i-butane ratio (denoted as [Propane]/[i-Butane]) is used throughout this analysis as a marker for $\mathrm{OH}$ oxidation. $\mathrm{OH}$ oxidation will cause [Propane]/[i-Butane] to increase because i-butane is oxidized by $\mathrm{OH}$ approximately 2.4 times faster than propane based on the reaction rate coefficients listed in Table 1. While [Propane]/[i-Butane] is sensitive to OH oxidation, it will not be affected by $\mathrm{Cl}$ oxidation as propane and i-butane have similar $\mathrm{Cl}$ reaction rate coefficients, which only differ by a factor of 1.03 .

$\mathrm{Cl}$ oxidation is indicated by decreases in [n-Butane]/[iButane]. n-Butane reacts 1.4 times faster with $\mathrm{Cl}$ than $\mathrm{i}$ butane. This ratio is not sensitive to $\mathrm{OH}$ oxidation as both isomers have similar $\mathrm{OH}$ reactivities within a factor of 1.04. Neither of the alkane ratios used as $\mathrm{OH}$ or $\mathrm{Cl}$ oxidation mark- ers will be affected by $\mathrm{Br}$. Br only reacts at appreciable rates with a select group of VOCs including ethene, acetylene, aldehydes, and some halocarbons. A decrease in [Acetylene]/[Benzene] is used throughout this study as an indicator of halogen oxidation as acetylene is more readily oxidized by both $\mathrm{Br}$ and $\mathrm{Cl}$ than benzene.

VOC ratios are generally less sensitive to dilution and mixing than the absolute concentrations of individual species (Parrish et al., 2007). We note that VOC ratios can be perturbed by 1) the mixing of air parcels that have been exposed to sources with disproportionate emission ratios of the specified hydrocarbons or 2) the mixing of air parcels that have been exposed to vastly different degrees of chemical processing. In the following discussions, we compare the variability in the VOC ratios to other trace gases in order to isolate the influence of halogen oxidation from any perturbations linked to the mixing of disparate air masses.

\subsection{Description of ICEALOT data subsets}

Figure 2a-e shows the time series for wind direction, temperature, $\mathrm{O}_{3}$ and the VOC ratios used as oxidation markers. At the start of the cruise, the R/V Knorr sampled off the northeastern coast of the United States (NE US). Much of the air sampled within this region is characterized as urban outflow where $\mathrm{O}_{3}$ was negatively correlated with $\mathrm{CO}$ and nitric oxide (NO, not shown) due to $\mathrm{NO}$ titration of $\mathrm{O}_{3}$. The ship briefly sampled a distinctly different air mass on 25 March 2008. The arrival of this air mass was signaled by an abrupt change in the wind direction, sharp increases in the air temperature and absolute humidity (not shown), and decreases in $\mathrm{O}_{3}$, CO, and certain VOCs. This air mass, determined to be sub-tropical in origin, was transported northward as a result of a mid-latitude cyclone positioned to the southwest of the ship. We do not further interpret the fine-scale variabilities of the VOC ratios in the NE US data subset, as the ratios were likely influenced by the mixing of urban or sub-tropical air masses with background air rather than by specific types of oxidation.

Within the sub-Arctic region, there were distinct decreases in $\mathrm{O}_{3}$ that were not associated with changes in wind direction, temperature, or $\mathrm{CO}$ (Fig. 2). For example, $\mathrm{O}_{3}$ decreased from 45 to $32 \mathrm{ppbv}$ on 28 March 2008. During this time, there were simultaneous decreases in [Acetylene]/[Benzene] and [n-Butane]/[i-Butane] while [Propane]/[i-Butane] remained constant indicating that this air mass was predominately exposed to halogen oxidation. FLEXPART indicates that this air mass originated in the Arctic before advecting over northeastern Canada, Baffin Bay, and the Davis Strait. Shortly after this period, the general paths of the air masses shifted from the western (Canadian) Arctic to the eastern (Siberian) Arctic. On 6 April 2008 when the R/V Knorr was positioned along the northern coast of Norway, another concurrent and prolonged decrease in [Acetylene]/[Benzene] and $\mathrm{O}_{3}$ was observed indicating the influence of halogen 

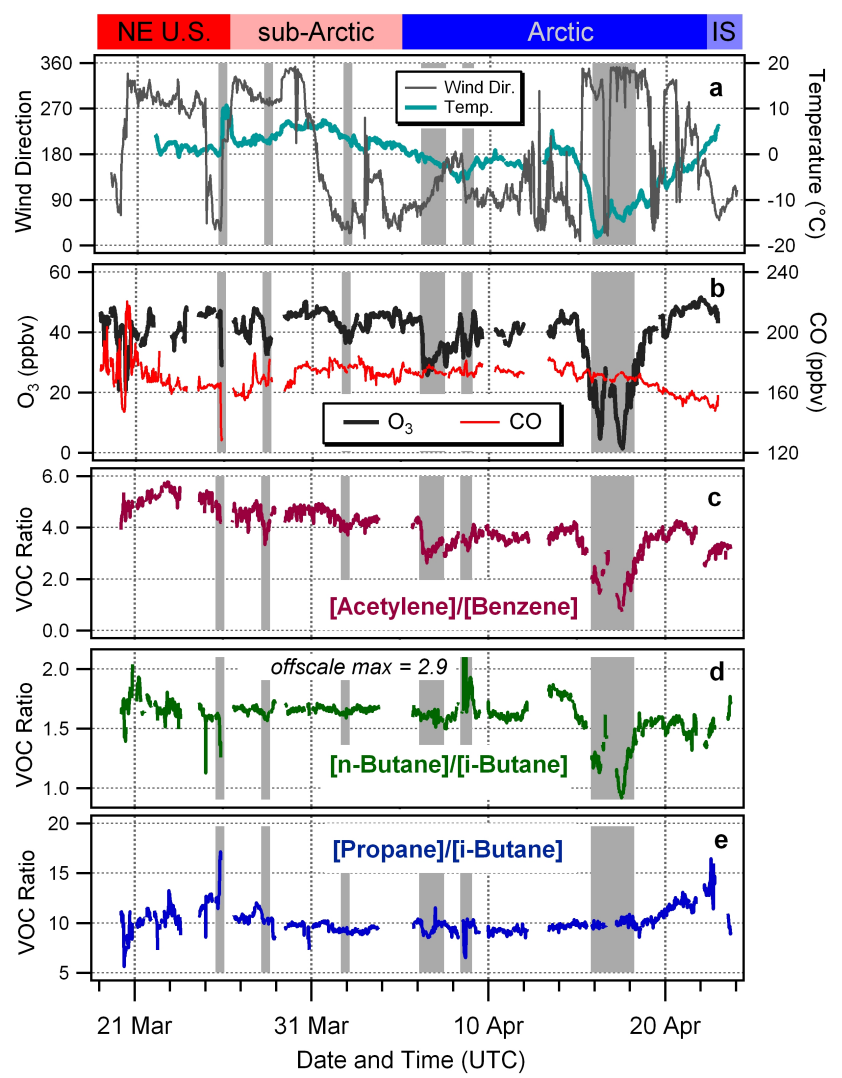

Fig. 2. Time series of (a) wind direction and ambient temperature, (b) $\mathrm{O}_{3}$ and $\mathrm{CO}$, (c) [Acetylene]/[Benzene] which is used as a marker for $\mathrm{Cl}$ and $\mathrm{Br}$ oxidation, (d) [n-butane]/[i-butane] which is used as a marker for $\mathrm{Cl}$ oxidation, (e) [Propane]/[i-butane] which is used as a marker for $\mathrm{OH}$ oxidation. The ICEALOT data subsets are delineated at the top. The grey bands highlight specific samples that are discussed in the text.

oxidation (Fig. 2); however, a small decrease in [Propane]/[iButane] points to the possible influence of the mixing of two air masses with different VOC emission source ratios or different degrees or types of chemical processing. FLEXPART determined that this air mass originated in the central/eastern Arctic, advected southward towards the Kola Peninsula, before shifting westward and advecting along the northern European coastline prior to interception by the ship.

A plume enriched in hydrocarbons was encountered on 8 April 2008 as the R/V Knorr traveled eastward towards the Norwegian/Russian border. The enrichment of the C3C5 alkanes, determined by comparing the maximum values listed in italics in Table 1 to their median values, increased according to carbon number and was greater for the linear alkanes compared to their branched isomers. This resulted in the sharp increase in [n-Butane]/[i-Butane] and decrease in [Propane]/[i-Butane] as shown in Fig. 2d and 2e, respectively. FLEXPART shows that this air mass had advected over the Kola Peninsula near the city of Murmansk, Rus- 
2008 suggesting that a halogen oxidized air mass may have been mixed with air that was at least partially enriched in alkanes.

A prolonged period of reduced $\mathrm{O}_{3}$ was observed from 1519 April 2008 when the ship was near the coast of Svalbard, Norway, and in close proximity $(0.5$ to $2.0 \mathrm{~km})$ to sea ice. During this time, the wind was predominately from the northnorthwest. The ambient temperature reached a minimum of $-18^{\circ} \mathrm{C}$, and $\mathrm{O}_{3}$ was reduced from $43 \mathrm{ppbv}$ to $1.5 \mathrm{ppbv}$ as shown in Fig. 2a, b. FLEXPART indicates that the air masses sampled throughout this time period were entirely Arctic in origin, having been confined to latitudes north of $80^{\circ} \mathrm{N}$ for the majority of their 20-day histories. The strong association between the time series of $\mathrm{O}_{3}$, [Acetylene]/[Benzene], and [n-Butane]/[i-Butane], as shown in Fig. 2b-e, indicates that this air mass had been exposed to both $\mathrm{Cl}$ and $\mathrm{Br}$ oxidation. The $[\mathrm{Br}] /[\mathrm{Cl}]$ ratio can be derived from the relative change in a VOC's mixing ratio from its "background" value (i.e., outside of an ODE) to that observed in a halogen oxidized air mass (Jobson et al., 1994; Ramacher et al., 1999). Lerner, et al. (2010) presents this type of analysis for the large-scale ODE encountered during ICEALOT and determined a mean $[\mathrm{Br}] /[\mathrm{Cl}]$ ratio of $1600 \pm 200$. This ratio is consistent with previously reported $[\mathrm{Br}] /[\mathrm{Cl}]$, which range from approximately 400 to 2000 (Jobson et al., 1994; Cavender et al., 2008).

The gradual increase in [Propane]/[i-Butane] from 20 April 2008 to the end of the cruise in Iceland (Fig. 2e) indicates the growing influence of $\mathrm{OH}$ chemistry in the Arctic and sub-Arctic in the late spring. During this time period, $\mathrm{CO}$ gradually decreased while $\mathrm{O}_{3}$ reached a campaign maximum of $51 \mathrm{ppbv}$. The atmospheric lifetime of $\mathrm{CO}$ is largely controlled by reaction with $\mathrm{OH}$, and $\mathrm{OH}$ radicals are responsible for the photochemical production of $\mathrm{O}_{3}$. FLEXPART indicates that the air masses sampled during this time had large footprint emission sensitivities to Eastern Europe. The previously noted changes in $\mathrm{CO}, \mathrm{O}_{3}$, and the VOC ratios towards the end of the campaign are likely influenced by the mixing of background air in the Arctic with air from more southerly regions where $\mathrm{OH}$ oxidation is increasingly important.

\subsection{Halogen oxidation and $\mathrm{O}_{3}$ variability}

A scatter plot of [Acetylene]/[Benzene] versus $\mathrm{O}_{3}$ is used here to assess the impact of halogen oxidation on the variability of surface $\mathrm{O}_{3}$. Figure 3a includes the ICEALOT data, which has been colored by latitude, as well as the linear regressions and corresponding correlation coefficients for the NE US $(r=0.30)$, sub-Arctic $(r=0.72)$, and Arctic $(r=0.98)$ data subsets. The correlation between [Acetylene]/[Benzene], which is sensitive to $\mathrm{Br}+\mathrm{Cl}$ oxidation, and $\mathrm{O}_{3}$ strengthened as the R/V Knorr sailed north towards the Arctic. The fit for the Arctic data subset shows a high degree of correlation with $\mathrm{r}=0.98$ for the 544 data points collected north of $68^{\circ} \mathrm{N}$. When the analysis is expanded to include the additional 347 data points collected in the sub-Arctic, the correlation for the combined Arctic and sub-Arctic region remains strong with $r=0.90$. The strength of the correlation between [Acetylene]/[Benzene] and $\mathrm{O}_{3}$ in the Arctic and sub-Arctic is remarkable given that the sources and atmospheric fates of these species are often quite different; however, one factor linking $\mathrm{O}_{3}$ and acetylene is their common sensitivity to halogen oxidation. The strong correlation between [Acetylene]/[Benzene] and $\mathrm{O}_{3}$ indicates that halogen oxidation accounted for up to $96 \%\left(r=0.98, r^{2}=0.96\right)$ of the variability in $\mathrm{O}_{3}$ measured in the Arctic marine boundary layer in the springtime during ICEALOT.

We have established for the ICEALOT dataset that concurrent reductions in [Acetylene]/[Benzene] and $\mathrm{O}_{3}$ can be accounted for by the oxidation of acetylene via $\mathrm{Cl}$ and $\mathrm{Br}$ and the destruction of surface $\mathrm{O}_{3}$ by $\mathrm{Br}$. These concurrent reductions result in the observed slope of the Arctic fit to the ICEALOT data set (Fig. 3a), which is determined by comparing Arctic "background" values (e.g., $\mathrm{O}_{3}=45 \mathrm{ppbv}$ and $[$ Acetylene $] /[$ Benzene $]=4.0)$ to air masses that have been exposed to halogen oxidation (e.g., $\mathrm{O}_{3}=1.5 \mathrm{ppbv}$ and $[$ Acetylene]/[Benzene] $=1.0)$. It is interesting to note that the slope of the sub-Arctic fit (Fig. 3a) is similar to that of the Arctic; however, the y-intercept is greater for the sub-Arctic data subset. As shown in Fig. 2, [Acetylene]/[Benzene] decreases from a mean value of 5 in the NE U.S. to a mean background value of approximately 4 in the Arctic. The offset in the [Acetylene]/[Benzene] for the sub-Arctic data subset is reflective of the waning influence of continental outflow from North America and the increasing influence of Arctic outflow as the R/V Knorr sailed northward. The observed slope, y-intercept, and strength of the correlation between [Acetylene]/[Benzene] and $\mathrm{O}_{3}$ for the sub-Arctic dataset indicates that halogen oxidation, which likely occurred in the Arctic high latitudes, influenced $\mathrm{O}_{3}$ variability in the subArctic.

Figure $3 \mathrm{~b}$ compares the ICEALOT dataset to other measurements in the Arctic and at coastal mid-latitudes in order to gauge the spatial extent of halogen oxidation influence on surface $\mathrm{O}_{3}$ variability. The data from two springtime studies in Alaska, ARCPAC and Barrow (BRW), exhibit similarly high degrees of correlation between [Acetylene]/[Benzene] and $\left[\mathrm{O}_{3}\right.$ ] with $r=0.81$ ( $r=0.98$ without the two outliers) and $r=0.89$, respectively, and the majority of the data from the Alaskan studies fall on the Arctic fit to the ICEALOT data collected on the opposite side of the Arctic. This implies that halogen oxidation can account for the vast majority of the observed $\mathrm{O}_{3}$ variability throughout the Arctic boundary layer during these springtime studies. The fact that the Alaskan studies have a similar slope as the Arctic fit to the ICEALOT data suggests that halogen oxidation chemistry may be comparable across the Arctic (i.e., similar reactant ratios and reaction conditions) and/or the mixing/dilution of halogen oxidized air masses within the arctic boundary layer do not significantly perturb the relationship between 
[Acetylene]/[Benzene] and $\mathrm{O}_{3}$. While it is difficult to distinguish between these scenarios with the available datasets, Jobson et al. (1994) suggested that the effects of mixing and dilution of air masses on VOC ratios measured within the Arctic will be minimal because of the narrow range of air mass photochemical ages.

Measurements from two mid-latitude coastal sites have been added to Fig. $3 \mathrm{~b}$ for comparison. The New England Air Quality Study (NEAQS) was conducted along the northeastern coast of the US aboard the NOAA R/V Brown in the summer of 2004 (Warneke et al., 2007). [Acetylene]/[Benzene] from NEAQS is comparable to that measured during the springtime ICEALOT cruise in a similar geographic region. However, [Acetylene]/[Benzene] and $\mathrm{O}_{3}$ were not significantly correlated in the NE US data subset $(r=0.30)$ or during NEAQS $(r=0.004)$ indicating that halogen oxidation was not a large factor in determining $\mathrm{O}_{3}$ variability in this region in either spring or summer. This is in accordance with the findings of Keene et al. (2007) who determined that $\mathrm{Br}$ chemistry is relatively unimportant in the evolution of polluted coastal air in this region.

The Observatory at Trinidad Head, California, (THD) is located along the Pacific coast at approximately the same latitude as the east coast studies (Fig. 1). Oltmans et al. (2008) determined that approximately $25 \%$ of the air masses reaching THD in April originate in northern Alaska and are transported at relatively low altitudes throughout their modeled 10-day trajectories. Figure $3 \mathrm{~b}$ shows that [Acetylene]/[Benzene] is independent of $\mathrm{O}_{3}$ at THD in late winter and spring. Even though a fraction of the air masses reaching THD in the spring may have originated in the Arctic, there is no indication that $\mathrm{O}_{3}$-poor air transported from the Arctic had an appreciable influence on surface $\mathrm{O}_{3}$ variability at THD for the samples analyzed. We note that the magnitude of [Acetylene]/[Benzene] is markedly lower for THD compared to the east coast studies. This is attributed to differences in source emission ratios (Warneke et al., 2007; Parrish et al., 2009) and transport patterns (Oltmans et al., 2008) impacting the Atlantic and Pacific Coasts.

\subsection{Modeled sea ice exposure}

FLEXPART was used to quantitatively determine the exposure of air masses intercepted by the R/V Knorr to first-year ice (FYI), multi-year ice (MYI), and total ICE (FYI+MYI). The term "exposure" used throughout this text is defined here as the modeled quantity (units of ppbv) of the specified type of inert FYI or MYI tracer, which is directly proportional to the time that an air mass was in contact with the specified types of sea ice. Examples of the modeling products used to determine the sea ice exposure for the air mass sampled on 2 April 2008 at 00:00 UTC are described here. Gas phase measurements from this period indicate that this air mass was exposed to halogen oxidation (refer to Fig. 2).
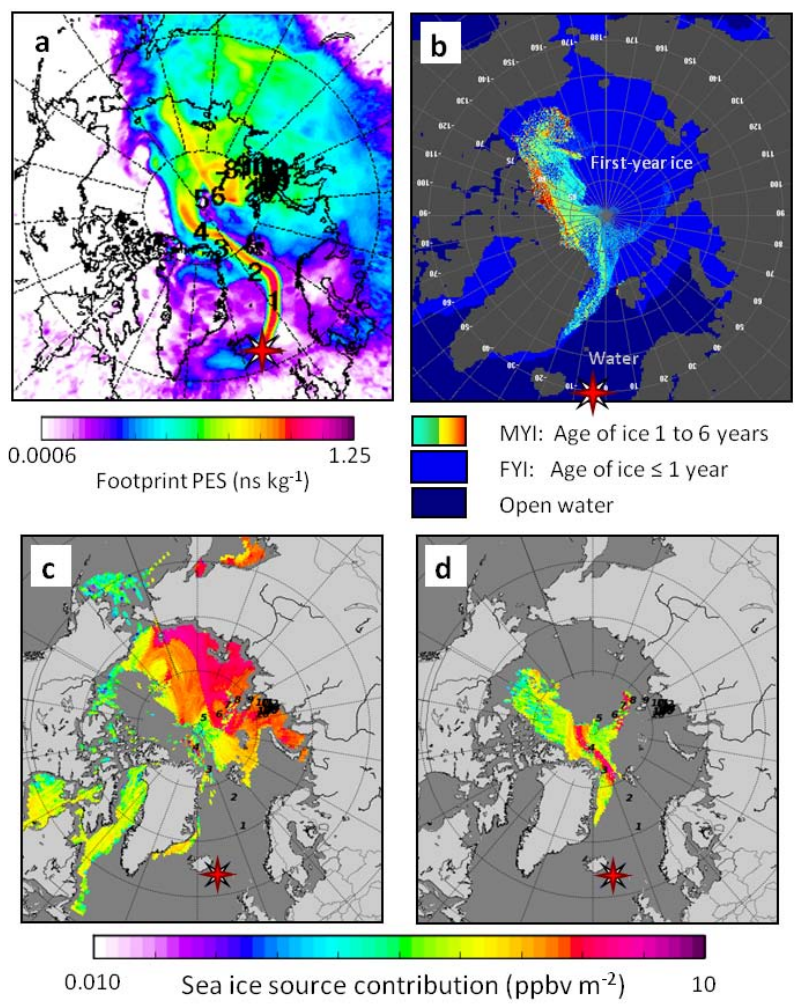

Fig. 4. (a) Circumpolar map of the FLEXPART modeled footprint potential emission sensitivity (PES) for the air mass sampled on 2 April 2008 at 00:00 UTC. The bold numbers represent the days of transport backward in time. (b) Map of the Arctic sea ice coverage colored by the modeled sea ice age for 1-7 April 2008. FLEXPART sea ice source contribution maps for (c) FYI and (d) MYI. The red star in panels $(\mathrm{a}-\mathrm{d})$ indicates the position of the R/V Knorr $\left(62.9^{\circ} \mathrm{N}\right.$, $\left.12.3^{\circ} \mathrm{E}\right)$.

A map of the FLEXPART footprint PES, shown in Fig. 4a, identifies where the released particles spent the most amount of time in the lowest $100 \mathrm{~m}$ of the atmosphere over their 20 day histories. The footprint PES map shows that this particular air mass remained largely intact for the first 5 days prior to arrival at the ship's location, but was broadly dispersed across the eastern Arctic further back in time. A map of the sea ice coverage colored by the modeled sea ice age for the week of 1-7 April 2008 is shown in Fig. 4b. The sea ice coverage was classified as FYI or MYI by the procedures outlined in Fowler et al. (2004).

The exposure of the sampled air mass to FYI or MYI was determined by folding the footprint PES with gridded sea ice coverage, which was assigned a unit emission flux of a FYI or MYI tracer. This results in the FYI and MYI source contribution maps shown in Fig. 4c and Fig. 4d, respectively, for the air intercepted on 2 April 2008 at 00:00 UTC. The sea ice source contribution maps (units of $\mathrm{ppbv} \mathrm{m}^{-2}$ ) depict the location and magnitude of the exposure of this particular air mass to FYI or MYI as quantified by the modeled abundance 


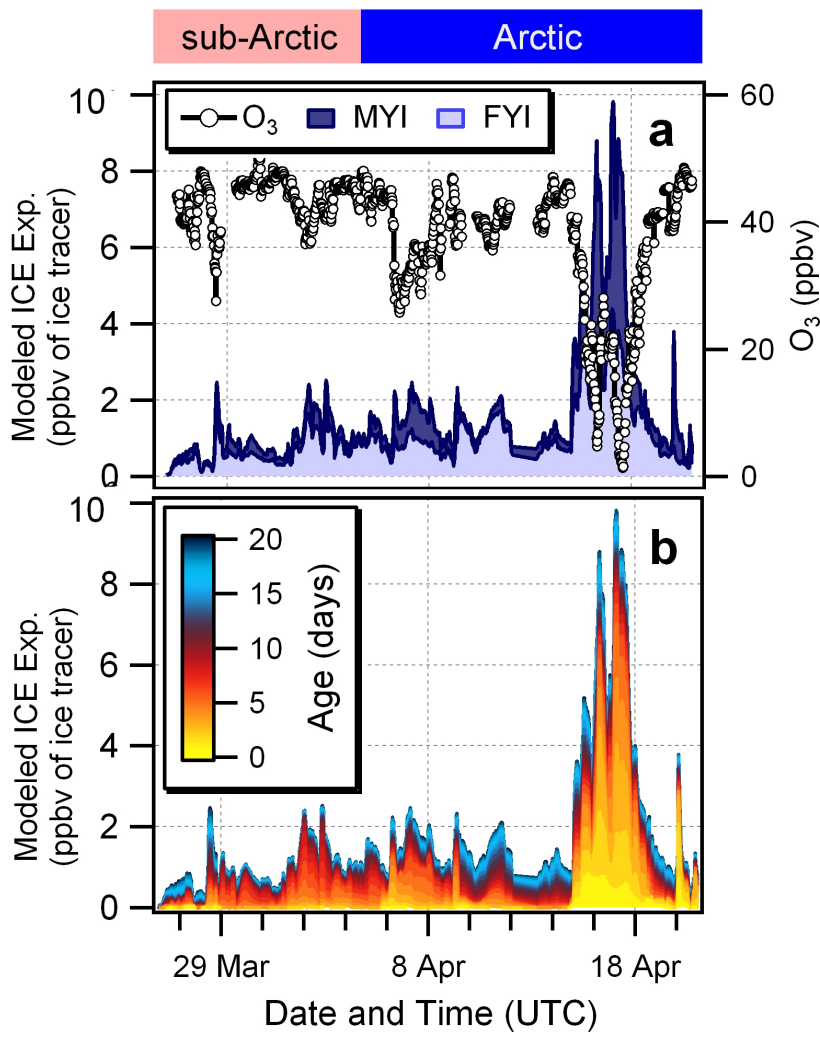

Fig. 5. (a) Time series of $\mathrm{O}_{3}$ and the modeled FYI and MYI exposure for the sub-Arctic and Arctic data subsets from ICEALOT. MYI has been stacked on FYI so that the combined height represents the total ICE (FYI + MYI) exposure. (b) Time series of total ICE exposure colored by FLEXPART age.

of the FYI or MYI ice tracer (units of ppbv) over its 20 day history. The maps in Fig. 4 show that this air mass was transported over open water for approximately 3 days prior to sampling, exposed primarily to MYI in the western Arctic for the days 3-5 prior to sampling, and exposed mainly to FYI in the Siberian Arctic for days 5-20 of its modeled history.

The time series of the cumulative 20-day modeled exposure to FYI and MYI are shown in Fig. 5a. The two time series are stacked so that the cumulative value is equal to the total ICE exposure, which is shown in Fig. 5b. On average, exposure to FYI accounts for $68 \pm 15 \%$ and MYI accounts for $32 \pm 15 \%$ of the absolute exposure to total sea ice for the sub-Arctic and Arctic data subsets. This roughly scales with the relative surface areas of the two ice classes (Fig. 4b). As shown in Fig. 5a, $\mathrm{O}_{3}$ exhibits a clear negative association with modeled ice exposure such that air masses with the greatest ICE exposure had the lowest measured $\mathrm{O}_{3}$. Additionally, air masses with the largest depletions in $\mathrm{O}_{3}$ (e.g., 6 April and 15-18 April 2008) have a larger than average contribution from MYI, which accounts for approximately $50-60 \%$ of the total ICE exposure for these events.
The time series of the total ICE exposure (Fig. 5b) is colored by the FLEXPART age, which is defined as the number of days backwards in time from the initial release of the particles. This figure shows that a wide range of FLEXPART ages contributed to the modeled ICE exposure. In the sub-Arctic region, air masses show larger contributions from the 5-15 day FLEXPART ages. This is in accordance with the greater time required for air masses exposed to sea ice covering the Arctic Ocean to be transported to latitudes as far south as $45^{\circ} \mathrm{N}$. Consistently, the air masses with the largest contribution from 1-5 day FLEXPART ages were encountered in the Arctic when the ship was in close proximity $(0.5$ to $2.0 \mathrm{~km})$ to sea ice.

The decrease in $\mathrm{O}_{3}$ on 28 March 2008, previously described in Sect. 3.1 and highlighted in Fig. 2b, corresponds with a sharp increase in the modeled ICE exposure. FLEXPART source contribution maps show that this air mass was in contact with FYI in the Davis Strait and both Hudson and Baffin Bays as recently as 2-3 days prior to arrival at the R/V Knorr, while it required over 10 days of transport for the air mass to be exposed to MYI within the Arctic. This marks the most southerly latitude, $52^{\circ} \mathrm{N}$, where an air mass with reduced $\mathrm{O}_{3}$ due to halogen chemistry could be directly linked to significant exposure to sea ice by FLEXPART.

\subsection{Correlations between $\mathrm{O}_{3}$ and modeled sea ice exposure}

Correlations between $\mathrm{O}_{3}$ and the modeled exposure to FYI, MYI, and total ICE is used to determine if the variability in $\mathrm{O}_{3}$ can be explained by the exposure to these types of sea ice. The depletion of $\mathrm{O}_{3}$ is used here as a proxy for the presence of reactive halogens; however, the actual amount of $\mathrm{O}_{3}$ destroyed is dependent on a number of variables including the initial concentration of $\mathrm{O}_{3}$ within the air mass, the absolute concentrations of the halogens, the relative ratio between $\mathrm{Br}$ and $\mathrm{Cl}$, and the reaction time in addition to several other factors.

If one type of ice were the dominant source of the reactive halogens responsible for the destruction of $\mathrm{O}_{3}$ (i.e., a source region of reactive halogens), one would expect to see a stronger correlation between the exposure to that particular type of ice and the amount of $\mathrm{O}_{3}$ destroyed assuming that all other reaction variables are similar.

The results of the linear correlations between the modeled exposures to FYI, MYI, and ICE versus $\mathrm{O}_{3}$ are shown in Fig. 6. The linear correlation coefficients, $r$, are plotted as a function of FLEXPART age in Fig. 6a and Fig. 6b for the Arctic and combined Arctic and sub-Arctic data subsets, respectively. The FLEXPART ages are cumulative so that, for example, the modeled exposure on day 5 represents the sum of the exposure for days 1-5 of an air mass's history.

All of the correlations between the modeled sea ice exposures and $\mathrm{O}_{3}$ are negative indicating that increased exposure to FYI, MYI, or ICE is directly associated with reduced 


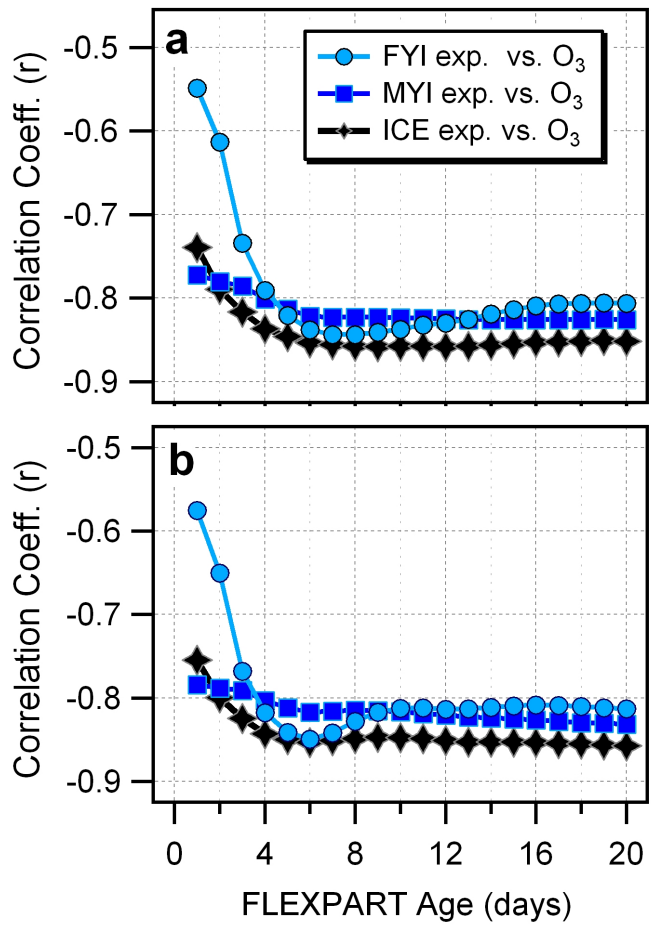

Fig. 6. Linear correlation coefficients for the modeled FYI, MYI, and ICE exposure versus $\mathrm{O}_{3}$ as a function of the FLEXPART age for (a) the Arctic and (b) combined Arctic and sub-Arctic data subsets.

levels of $\mathrm{O}_{3}$ in the Arctic and sub-Arctic marine boundary layer during the spring. $\mathrm{O}_{3}$ correlated best with total ICE exposure for both data subsets. A mean correlation coefficient for ICE of $r=-0.86 \pm 0.03\left(r^{2}=0.73\right)$ suggests that up to $73 \%$ of the $\mathrm{O}_{3}$ variability measured in the Arctic can be related to the modeled exposure to total ICE. As a sensitivity test, the correlation coefficients were also calculated for the same data subsets, but without the large-scale $\mathrm{O}_{3}$ depletion. The correlation coefficient weakened from -0.86 to -0.60 indicating that this ODE was important but not solely responsible for the observed correlation between $\mathrm{O}_{3}$ and the modeled ICE exposure.

There were very few air masses which had significant exposure to FYI within days $1-3$ of its transport history resulting in poorer correlation coefficients for these FLEXPART ages. FYI appears to be slightly better correlated with $\mathrm{O}_{3}$ than MYI for the 4-10 day ages, but the differences between exposure to FYI and MYI are small. This was partly due to the fact that the exposures to FYI and MYI were generally well correlated with one another $(0.70<r<0.87)$ indicating that the air masses were sufficiently well dispersed so that they were often in contact with both types of ice at the same time. As a result of this co-linearity, the relative importance of exposure to FYI or MYI in determining $\mathrm{O}_{3}$ variability remains inconclusive for the ICEALOT data set.

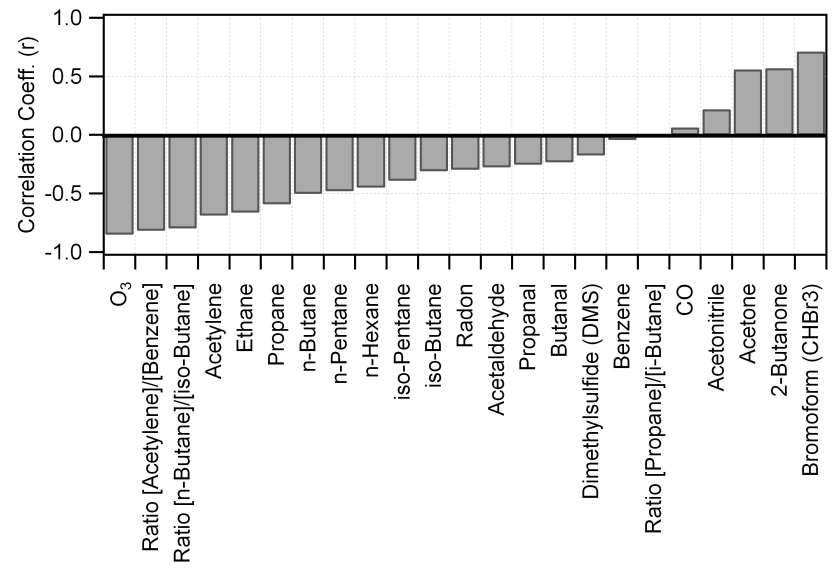

Fig. 7. Linear correlation coefficients for the 6-day cumulative modeled ICE exposure versus various gas-phase measurements made in the Arctic during ICEALOT.

The correlation coefficients for FYI, MYI and total ICE remain strong $(r<-0.80)$ for all FLEXPART ages greater than 4 days. Here we examine the relative contribution of the total ICE exposure amassed in days 15-20 compared to the cumulative 20-day exposure in order to determine the fraction of air masses that remain over the sea ice in the Arctic footprint layer (i.e., lowest $100 \mathrm{~m}$ of the atmosphere) throughout their modeled histories. The median fractional contribution of the exposure amassed in days 15-20 compared to the cumulative 20 day air mass history is 0.18 for the Arctic data subset, indicating that $18 \%$ of the modeled exposure to total ICE occurred during the oldest 5 days of its 20-day history. This is not a negligible fraction of the cumulative exposure suggesting that the lifetimes of certain air masses within the Arctic boundary layer can be quite long. This is in general agreement with the results of Stohl (2006) who used FLEXPART in a long-term global simulation of transport into the Arctic. It was determined in that study that the mean "arctic age," defined as the time the air resides continuously north of $70^{\circ} \mathrm{N}$ increased from 7 days in the winter to 14 days in the summer.

\subsection{Correlations between other gases and modeled sea ice exposure}

The modeled sea ice exposure is compared to other trace gases measured aboard the R/V Knorr in order to demonstrate the sensitivity of the model to the source region where halogen oxidation chemistry likely occurs. The linear correlation coefficients for the 6-day cumulative ICE exposure versus various gas-phase measurements made in the Arctic are compiled in Fig. 7. The 6-day ICE exposure was chosen because it represents the shortest amount of time to produce the strongest correlation with $\mathrm{O}_{3}$ (Fig. 6a). $\mathrm{O}_{3}$ and the halogen oxidation markers [Acetylene]/[Benzene] and [iButane]/[n-Butane] have the strongest negative correlations. 
This is consistent with the variability of these species being heavily influenced by halogen oxidation. [Acetylene]/[Benzene] has a stronger correlation with ICE exposure than acetylene alone reiterating the facts that 1) destruction of acetylene by halogen oxidation drives the variability of [Acetylene]/[Benzene], and 2) the ratio is less sensitive to the influence of mixing and dilution than the absolute mixing ratio of acetylene alone.

The correlation coefficients for the C2-C6 alkanes are negative and generally increase with increasing carbon number. The oxidation of alkanes by $\mathrm{Cl}$ produces aldehydes and ketones, but the differences in the reactivities of these oxidized products with $\mathrm{Cl}$ and $\mathrm{Br}$ also influence their abundance. Aldehydes are highly reactive with both $\mathrm{Cl}$ and $\mathrm{Br}$ resulting in their reduction during ODEs on short timescales (Cavender et al., 2008). This is in accordance with the negative correlations of aldehydes with ICE exposure shown in Fig. 7. Ketones are produced from alkane $+\mathrm{Cl}$ reaction faster than they are destroyed by ketone $+\mathrm{Cl}$ reaction (Cavender et al., 2008). The net production of ketones from halogen oxidation results in the positive correlation. High concentrations of ketones have also been found in the snow-pack (Domine and Shepson, 2002; Grannas et al., 2002). Emissions of these compounds from the snow would further strengthen the positive correlation between ketones and ICE exposure.

Both radon and dimethyl sulfide (DMS) have weakly negative correlations with ICE exposure, which are qualitatively examined here. Atmospheric sources of radon are land-based whereas DMS is of oceanic origin (Ferek et al., 1995); therefore, the concentrations of these species are expected to be smaller in air masses that have been exposed to ICE rather than land or open water. Additionally, DMS can react with $\mathrm{BrO}$ (Barnes et al., 1991), which is an intermediate species that is present in elevated levels during ODEs (Hausmann and Platt, 1994; Neuman et al., 2010). Therefore, the oxidation of DMS by $\mathrm{BrO}$ would further enhance the negative correlation between DMS and ICE exposure.

Conversely, trace gases with atmospheric sinks other than ICE should exhibit positive correlations. The more time that an air parcel is exposed to sea ice, the lower the possibility of surface uptake by exposure to open water or land. This is true for acetonitrile, which has an oceanic sink (de Gouw et al., 2003; Jost et al., 2003). Benzene, CO, and [Propane]/[iButane], which is used here as an $\mathrm{OH}$ oxidation marker, have the weakest correlations with ICE exposure $(r<0.05)$. Compounds like benzene and $\mathrm{CO}$ have relatively long atmospheric lifetimes, are not sensitive to halogen oxidation, and do not have strong sources or sinks within the ice- and snowcovered Arctic.

Bromoform $\left(\mathrm{CHBr}_{3}\right)$ exhibits the strongest positive correlation with ICE exposure $(r=0.71)$. Like DMS, $\mathrm{CHBr}_{3}$ has known oceanic sources (Cota and Sturges, 1997). If the presence of $\mathrm{CHBr}_{3}$ is simply due to its oceanic source, it would be expected to have a negative correlation as does DMS even though the sources of DMS and $\mathrm{CHBr}_{3}$ within the ocean can be quite different. The strong positive correlation between $\mathrm{CHBr}_{3}$ and the modeled ICE exposure suggests that sea ice is possibly a direct source of $\mathrm{CHBr}_{3}$ and/or $\mathrm{CHBr}_{3}$ may be produced during $\mathrm{O}_{3}$ depletion chemistry.

\section{Summary}

The influence of halogen oxidation on the variability of $\mathrm{O}_{3}$ and VOCs in the Arctic and sub-Arctic boundary layer was investigated using field measurements from multiple studies conducted in March and April 2008 as part of the POLARCAT project. Ship-based measurements conducted in the ice-free regions of the North Atlantic and Arctic Oceans significantly expanded upon the existing spatial and temporal database of VOCs in the Arctic and sub-Arctic springtime marine boundary layer. The wide geographic area sampled by the ship provided unique insights on the influence of halogen destruction of surface $\mathrm{O}_{3}$ in the northern high latitudes and the transport of $\mathrm{O}_{3}$-poor air masses from the Arctic Basin to latitudes as far south as $52^{\circ} \mathrm{N}$.

The VOC ratios [Propane]/[i-Butane], [n-Butane]/[iButane], and [Acetylene]/[Benzene] were used as markers for of $\mathrm{OH}, \mathrm{Cl}$, and $\mathrm{Br}+\mathrm{Cl}$ oxidation, respectively. The correlation between [Acetylene]/[Benzene] and $\mathrm{O}_{3}$ was used to assess the influence of halogen oxidation on surface $\mathrm{O}_{3}$ variability. This correlation strengthened as the R/V Knorr sailed northward towards the Arctic. $\mathrm{O}_{3}$ was highly correlated with [Acetylene]/[Benzene] with $r=0.98$ for the 544 data points collected north of $68^{\circ} \mathrm{N}$ suggesting that halogen oxidation accounted for up to $96 \%$ of the variability in $\mathrm{O}_{3}$ measured in the springtime Arctic marine boundary layer during this study.

The strong correlation between [Acetylene]/[Benzene] and $\mathrm{O}_{3}$ observed aboard the ship was substantiated by concurrent airborne and ground-based measurements within the Alaskan Arctic. This implies that halogen oxidation can account for the vast majority of the observed $\mathrm{O}_{3}$ variability throughout the Arctic boundary layer during these springtime studies. The analysis was further expanded to include the sub-Arctic $\left(45^{\circ} \mathrm{N}\right.$ to $\left.68^{\circ} \mathrm{N}\right)$ and two coastal mid-latitude sites $\left(\sim 40^{\circ} \mathrm{N}\right)$ in order to investigate the broader, spatialscale variations in $\mathrm{O}_{3}$. The results of this analysis indicated that halogen oxidation, which likely occurred in the Arctic high latitudes, influenced $\mathrm{O}_{3}$ variability in the sub-Arctic; however, this influence did not extend to either of the coastal mid-latitude sites. The potential of this influence of Arctic air on more southerly latitudes warrants further investigation.

FLEXPART, a Lagrangian particle dispersion model, was used to quantitatively determine the exposure of air masses intercepted by the ship to first-year ice (FYI), multi-year ice (MYI), and ICE (FYI+MYI). The modeled sea ice exposures were negatively correlated with $\mathrm{O}_{3}$ indicating that increased exposure to all types of Arctic sea ice was associated with reduced levels of $\mathrm{O}_{3}$ in the Arctic and sub-Arctic marine 
boundary layer during this springtime study. The modeled ICE exposure was compared to other gases measured aboard the R/V Knorr. Compounds that were negatively correlated with sea ice emissions were those that are readily oxidized by the reactive halogens $\mathrm{Cl}$ or $\mathrm{Br}$ or have atmospheric sources other than sea ice (e.g., ocean or land). Species that exhibited positive correlations were those that are produced from halogen oxidation or have atmospheric sinks other than sea-ice (e.g., ocean uptake or deposition). $\mathrm{CHBr}_{3}$ had the strongest positive correlation with the modeled ICE exposure $(r=0.71)$, suggesting that arctic sea ice is possibly a direct source of $\mathrm{CHBr}_{3}$ and/or $\mathrm{CHBr}_{3}$ may be produced during $\mathrm{O}_{3}$ depletion chemistry.

Acknowledgements. The authors would like to thank the crew members and fellow scientists aboard the R/V Knorr and the NOAA WP-3D for their help and expertise. The radon measurements aboard the R/V Knorr were provided by J. E. Johnson and T. S. Bates of NOAA's Pacific Marine Environmental Laboratory. The authors thank the station personnel responsible for filling flasks and overseeing the $\mathrm{O}_{3}$ monitors at BRW and THD. Results from BRW, THD, and from the NWAS during ARCPAC were supported in part by the Atmospheric Composition and Climate Program of NOAA's Climate Program Office. Support of the FLEXPART analysis for this study was provided by the Norwegian Research Council through the POLARCAT project (NFR\#175916).

Edited by: J. W. Bottenheim

\section{References}

Atkinson, R. and Aschmann, S. A.: Kinetics of the gas phase reaction of $\mathrm{Cl}$ atoms with a series of organics at $296+/-2 \mathrm{~K}$ and atmospheric pressure, Int. J. Chem. Kinet., 17, 33-41, 1985.

Atkinson, R.: Kinetics and mechanisms of the gas-phase reactions of the hydroxyl radical with organic-compounds under atmospheric conditions, Chem. Rev., 86, 69-201, 1986.

Atkinson, R., Baulch, D. L., Cox, R. A., Crowley, J. N., Hampson, J. R. F., Kerr, J. A., Rossi, M. J., and Troe, J.: Summary of evaluated kinetic and photochemical data for atmospheric chemistry, IUPAC Gas Kinetic Data Evalu. for Atmos. Chem., Web Version December 2001, 1-56, 2001.

Atkinson, R.: Kinetics of the gas-phase reactions of $\mathrm{OH}$ radicals with alkanes and cycloalkanes, Atmos. Chem. Phys., 3, 22332307, 2003,

http://www.atmos-chem-phys.net/3/2233/2003/.

Barnes, I., Bastian, V., Becker, K. H., and Overath, R. D.: Kinetic studies of the reactions of $\mathrm{IO}, \mathrm{BrO}$, and $\mathrm{ClO}$ with dimethylsulfide, Int. J. Chem. Kinet., 23, 579-591, 1991.

Barnes, I., Becker, K. H., and Overath, R. D.: Oxidation of organic sulfur compounds, in: Tropospheric Chemistry of Ozone in Polar Regions, edited by: Niki, H., and Becker, K. H., SpringerVerlang, New York, USA, 1993.

Barrie, L. and Platt, U.: Arctic tropospheric chemistry: an overview, Tellus B, 49, 450-454, 1997.

Barrie, L. A., Bottenheim, J. W., Schnell, R. C., Crutzen, P. J., and Rasmussen, R. A.: Ozone destruction and photochemical reac- tions at polar sunrise in the lower Arctic atmosphere, Nature, 334, 138-141, 1988.

Bates, T. S., Quinn, P. K., Coffman, D., Schulz, K., Covert, D. S., Johnson, J. E., Williams, E. J., Lerner, B. M., Angevine, W. M., Tucker, S. C., Brewer, W. A., and Stohl, A.: Boundary layer aerosol chemistry during TexAQS/GoMACCS 2006: Insights into aerosol sources and transformation processes, J. Geophys. Res.-Atmos., 113, D00F01, doi:10.1029/2008jd010023, 2008.

Belchansky, G. I., Douglas, D. C., and Platonov, N. G.: Spatial and temporal variations in the age structure of Arctic sea ice, Geophys. Res. Lett., 32, L18504, doi:10.1029/2005g1023976, 2005.

Bottenheim, J. W., Barrie, L. A., Atlas, E., Heidt, L. E., Niki, H., Rasmussen, R. A., and Shepson, P. B.: Depletion of lower tropospheric ozone during Arctic spring - The Polar Sunrise Experiment 1988, J. Geophys. Res.-Atmos., 95, 18555-18568, 1990.

Bottenheim, J. W., Netcheva, S., Morin, S., and Nghiem, S. V.: Ozone in the boundary layer air over the Arctic Ocean: measurements during the TARA transpolar drift 2006-2008, Atmos. Chem. Phys., 9, 4545-4557, doi:10.5194/acp-9-4545-2009, 2009.

Cavender, A. E., Biesenthal, T. A., Bottenheim, J. W., and Shepson, P. B.: Volatile organic compound ratios as probes of halogen atom chemistry in the Arctic, Atmos. Chem. Phys., 8, 17371750, doi:10.5194/acp-8-1737-2008, 2008.

Cota, G. F. and Sturges, W. T.: Biogenic bromine production in the Arctic, Mar. Chem., 56, 181-192, 1997.

Cuevas, C. A., Notario, A., Martinez, E., and Albaladejo, J.: Temperature-dependence study of the gas-phase reactions of atmospheric $\mathrm{Cl}$ atoms with a series of aliphatic aldehydes, Atmos. Environ., 40, 3845-3854, doi:10.1016/j.atmosenv.2006.03.001, 2006.

de Gouw, J. A., Goldan, P. D., Warneke, C., Kuster, W. C., Roberts, J. M., Marchewka, M., Bertman, S. B., Pszenny, A. A. P., and Keene, W. C.: Validation of proton transfer reaction-mass spectrometry (PTR-MS) measurements of gas-phase organic compounds in the atmosphere during the New England Air Quality Study (NEAQS) in 2002, J. Geophys. Res.-Atmos., 108, D214682, doi:10.1029/2003jd003863, 2003.

DeMore, W. B., Sander, S. P., Golden, D. M., Hampson, R. F., Kurylo, M. J., Howard, C. J., Ravishankara, A. R., Kolb, C. E., and Molina, M. J.: Chemical kinetics and photochemical data for use in stratospheric modeling. Evaluation number 12, JPL Pub., 1-266, 1997.

Domine, F. and Shepson, P. B.: Air-snow interactions and atmospheric chemistry, Science, 297, 1506-1510, 2002.

Ferek, R. J., Hobbs, P. V., Radke, L. F., Herring, J. A., Sturges, W. T., and Cota, G. F.: Dimethyl sulfide in the arctic atmosphere, J. Geophys. Res.-Atmos., 100, 26093-26104, 1995.

Fowler, C., Emery, W. J., and Maslanik, J.: Satellite-derived evolution of Arctic sea ice age: October 1978 to March 2003, IEEE Geosci. Remote S., 1, 71-74, doi:10.1109/lgrs.2004.824741, 2004.

Gerbig, C., Schmitgen, S., Kley, D., Volz-Thomas, A., Dewey, K., and Haaks, D.: An improved fast-response vacuum-UV resonance fluorescence CO instrument, J. Geophys. Res.-Atmos., 104, 1699-1704, 1999.

Goldan, P. D., Kuster, W. C., Williams, E., Murphy, P. C., Fehsenfeld, F. C., and Meagher, J.: Nonmethane hydrocarbon and oxy hydrocarbon measurements during the 2002 New England 
Air Quality Study, J. Geophys. Res.-Atmos., 109, D21309, doi:10.1029/2003JD004455, 2004.

Grannas, A. M., Shepson, P. B., Guimbaud, C., Sumner, A. L., Albert, M., Simpson, W., Domine, F., Boudries, H., Bottenheim, J., Beine, H. J., Honrath, R., and Zhou, X. L.: A study of photochemical and physical processes affecting carbonyl compounds in the Arctic atmospheric boundary layer, Atmos. Environ., 36, 2733-2742, 2002.

Hausmann, M., and Platt, U.: Spectroscopic measurement of bromine oxide and ozone in the high Arctic during Polar Sunrise Experiment 1992, J. Geophys. Res.-Atmos., 99, 25399-25413, 1994.

Hirdman, D., Sodemann, H., Eckhardt, S., Burkhart, J. F., Jefferson, A., Mefford, T., Quinn, P. K., Sharma, S., Strom, J., and Stohl, A.: Source identification of short-lived air pollutants in the Arctic using statistical analysis of measurement data and particle dispersion model output, Atmos. Chem. Phys., 10, 669-693, doi:10.5194/acp-10-669-2010, 2010.

Hopper, J. F., Barrie, L. A., Silis, A., Hart, W., Gallant, A. J., and Dryfhout, H.: Ozone and meteorology during the 1994 Polar Sunrise Experiment, J. Geophys. Res.-Atmos., 103, 1481-1492, 1998.

Jobson, B. T., Niki, H., Yokouchi, Y., Bottenheim, J., Hopper, F., and Leaitch, R.: Measurements of C2-C6 hydrocarbons during the Ploar Sunrise 1992 Experiment - Evidence for $\mathrm{Cl}$ and Br atom chemistry, J. Geophys. Res.-Atmos., 99, 25355-25368, 1994.

Jost, C., Trentmann, J., Sprung, D., Andreae, M. O., and Dewey, K.: Deposition of acetonitrile to the Atlantic Ocean off Namibia and Angola and its implications for the atmospheric budget of acetonitrile, Geophys. Res. Lett., 30, 1837, doi:10.1029/2003g1017347, 2003.

Kaleschke, L., Richter, A., Burrows, J., Afe, O., Heygster, G., Notholt, J., Rankin, A. M., Roscoe, H. K., Hollwedel, J., Wagner, T., and Jacobi, H. W.: Frost flowers on sea ice as a source of sea salt and their influence on tropospheric halogen chemistry, Geophys. Res. Lett., 31, L16114, doi:10.1029/2004g1020655, 2004.

Kamboures, M. A., Hansen, J. C., and Francisco, J. S.: A study of the kinetics and mechanisms involved in the atmospheric degradation of bromoform by atomic chlorine, Chem. Phys. Lett., 353, 335-344, 2002

Keene, W. C., Stutz, J., Pszenny, A. A. P., Maben, J. R., Fischer, E. V., Smith, A. M., von Glasow, R., Pechtl, S., Sive, B. C., and Varner, R. K.: Inorganic chlorine and bromine in coastal New England air during summer, J. Geophys. Res.-Atmos., 112, D10S12, doi:10.1029/2006jd007689, 2007.

Lerner, B. M., Gilman, J. B., Murphy, P. C., Kuster, W. C., Burkhart, J. F., Stohl, A., Hermansen, O., Wolfe, D., Hazen, D., de Gouw, J. A., and Williams, E. J.: Observation and characterization of ozone depletion events in the Arctic Ocean during ICEALOT, in preparation, 2010.

Martin, S., Drucker, R., and Fort, M.: A laboratory study of frost flower growth on the surface of young sea ice, J. Geophys. Res.Oceans, 100, 7027-7036, 1995.

McConnell, J. C., Henderson, G. S., Barrie, L., Bottenheim, J., Niki, H., Langford, C. H., and Templeton, E. M. J.: Photochemical bromine production implicated in Arctic boundary layer ozone depletion, Nature, 355, 150-152, 1992.

Montzka, S. A., Myers, R. C., Butler, J. H., Elkins, J. W., and Cum- mings, S. O.: Global tropospheric distribution and calibration scale of HCFC-22, Geophys. Res. Lett., 20, 703-706, 1993.

Neuman, J. A., Nowak, J. B., Huey, L. G., Burkholder, J. B., Dibb, J. E., Holloway, J. S., Liao, J., Peischl, J., Roberts, J. M., Ryerson, T. B., Scheuer, E., Stark, H., Stickel, R. E., Tanner, D. J., and Weinheimer, A.: Bromine measurements in ozone depleted air over the Arctic Ocean, Atmos. Chem. Phys., 10, 6503-6514, 10,

http://www.atmos-chem-phys.net/10/6503/10/.5194/acp-106503-2010, 2010.

Notz, D. and Worster, M. G.: In situ measurements of the evolution of young sea ice, J. Geophys. Res.-Oceans, 113, C03001, doi:10.1029/2007jc004333, 2008.

Oltmans, S. J. and Komhyr, W. D.: Surface ozone distributions and variations from 1973-1984 Measurements at the NOAA Geophysical Monitoring for Climatic-Change Base-line Observatories, J. Geophys. Res.-Atmos., 91, 5229-5236, 1986.

Oltmans, S. J., Schnell, R. C., Sheridan, P. J., Peterson, R. E., Li, S. M., Winchester, J. W., Tans, P. P., Sturges, W. T., Kahl, J. D., and Barrie, L. A.: Seasonal surface ozone and filterable bromine relationship in the high Arctic, Atmos. Environ., 23, 2431-2441, 1989.

Oltmans, S. J. and Levy, H.: Surface ozone measurements from a global network, Atmos. Environ., 28, 9-24, 1994.

Oltmans, S. J., Lefohn, A. S., Harris, J. M., and Shadwick, D. S.: Background ozone levels of air entering the west coast of the US and assessment of longer-term changes, Atmos. Environ., 42, 6020-6038, doi:10.1016/j.atmosenv.2008.03.034, 2008.

Parrish, D. D., Stohl, A., Forster, C., Atlas, E. L., Blake, D. R., Goldan, P. D., Kuster, W. C., and de Gouw, J. A.: Effects of mixing on evolution of hydrocarbon ratios in the troposphere, J. Geophys. Res.-Atmos., D10S34, doi:10.1029/2006jd007583, 2007.

Parrish, D. D., Kuster, W. C., Shao, M., Yokouchi, Y., Kondo, Y., Goldan, P. D., de Gouw, J. A., Koike, M., and Shirai, T.: Comparison of air pollutant emissions among mega-cities, Atmos. Environ., 43, 6435-6441, doi:10.1016/j.atmosenv.2009.06.024, 2009.

Ramacher, B., Rudolph, J., and Koppmann, R.: Hydrocarbon measurements during tropospheric ozone depletion events: Evidence for halogen atom chemistry, J. Geophys. Res.-Atmos., 104, 3633-3653, 1999.

Ramacher, B., Orlando, J. J., and Tyndall, G. S.: Temperaturedependent rate coefficient measurements for the reaction of bromine atoms with a series of aldehydes, Int. J. Chem. Kinet., 32, 460-465, 2000.

Ridley, B. A., Atlas, E. L., Montzka, D. D., Browell, E. V., Cantrell, C. A., Blake, D. R., Blake, N. J., Cinquini, L., Coffey, M. T., Emmons, L. K., Cohen, R. C., DeYoung, R. J., Dibb, J. E., Eisele, F. L., Flocke, F. M., Fried, A., Grahek, F. E., Grant, W. B., Hair, J. W., Hannigan, J. W., Heikes, B. J., Lefer, B. L., Mauldin, R. L., Moody, J. L., Shetter, R. E., Snow, J. A., Talbot, R. W., Thornton, J. A., Walega, J. G., Weinheimer, A. J., Wert, B. P., and Wimmers, A. J.: Ozone depletion events observed in the high latitude surface layer during the TOPSE aircraft program, J. Geophys. Res.-Atmos., 108, 8356, doi:10.1029/2001jd001507, 2003.

Ryerson, T. B., Buhr, M. P., Frost, G. J., Goldan, P. D., Holloway, J. S., Hubler, G., Jobson, B. T., Kuster, W. C., McKeen, S. A., Parrish, D. D., Roberts, J. M., Sueper, D. T., Trainer, M., Williams, J., and Fehsenfeld, F. C.: Emissions lifetimes and ozone for- 
mation in power plant plumes, J. Geophys. Res.-Atmos., 103, 22569-22583, 1998.

Seibert, P. and Frank, A.: Source-receptor matrix calculation with a Lagrangian particle dispersion model in backward mode, Atmos. Chem. Phys., 4, 51-63, doi:10.5194/acp-4-51-2004, 2004.

Simpson, W. R., Carlson, D., Honninger, G., Douglas, T. A., Sturm, M., Perovich, D., and Platt, U.: First-year sea-ice contact predicts bromine monoxide $(\mathrm{BrO})$ levels at Barrow, Alaska better than potential frost flower contact, Atmos. Chem. Phys., 7, 621-627, doi:10.5194/acp-7-621-2007, 2007a.

Simpson, W. R., von Glasow, R., Riedel, K., Anderson, P., Ariya, P., Bottenheim, J., Burrows, J., Carpenter, L. J., Friess, U., Goodsite, M. E., Heard, D., Hutterli, M., Jacobi, H. W., Kaleschke, L., Neff, B., Plane, J., Platt, U., Richter, A., Roscoe, H., Sander, R., Shepson, P., Sodeau, J., Steffen, A., Wagner, T., and Wolff, E.: Halogens and their role in polar boundary-layer ozone depletion, Atmos. Chem. Phys., 7, 4375-4418, doi:10.5194/acp-74375-2007, 2007b.

Solberg, S., Schmidbauer, N., Semb, A., Stordal, F., and Hov, O.: Boundary-layer ozone depletion as seen in the Norwegian Arctic in Spring, J. Atmos. Chem., 23, 301-332, 1996.

Stohl, A., Hittenberger, M., and Wotawa, G.: Validation of the Lagrangian particle dispersion model FLEXPART against largescale tracer experiment data, Atmos. Environ., 32, 4245-4264, 1998.

Stohl, A., Eckhardt, S., Forster, C., James, P., Spichtinger, N., and Seibert, P.: A replacement for simple back trajectory calculations in the interpretation of atmospheric trace substance measurements, Atmos. Environ., 36, 4635-4648, 2002.

Stohl, A., Forster, C., Eckhardt, S., Spichtinger, N., Huntrieser, H., Heland, J., Schlager, H., Wilhelm, S., Arnold, F., and Cooper, O.: A backward modeling study of intercontinental pollution transport using aircraft measurements, J. Geophys. Res.-Atmos., 108, 4370, doi:10.1029/2002jd002862, 2003.

Stohl, A., Forster, C., Frank, A., Seibert, P., and Wotawa, G.: Technical note: The Lagrangian particle dispersion model FLEXPART version 6.2, Atmos. Chem. Phys., 5, 2461-2474, doi:10.5194/acp-5-2461-2005, 2005.

Stohl, A.: Characteristics of atmospheric transport into the Arctic troposphere, J. Geophys. Res.-Atmos., 111, D11306, doi:10.1029/2005jd006888, 2006.

Sturges, W. T., Schnell, R. C., Landsberger, S., Oltmans, S. J., Harris, J. M., and Li, S. M.: Chemical and meterological influences on surface ozone destruction at Barrow, Alaska, during Spring 1989, Atmos. Environ., 27, 2851-2863, 1993.
Wagner, T., Leue, C., Wenig, M., Pfeilsticker, K., and Platt, U.: Spatial and temporal distribution of enhanced boundary layer $\mathrm{BrO}$ concentrations measured by the GOME instrument aboard ERS2, J. Geophys. Res.-Atmos., 106, 24225-24235, 2001.

Wallington, T. J., and Kurylo, M. J.: The gas-phase reactions of hydroxyl radicals with a series of aliphatic alcohols over the temperature range 240-440 K, Int. J. Chem. Kinet., 19, 1015-1023, 1987.

Wallington, T. J., Skewes, L. M., and Siegl, W. O.: Kinetics of the gas-phase reaction of chlorine atoms with a series of alkenes, alkynes and aromatic species at $298 \mathrm{~K}$, J Photoch. Photobio. A, 45, 167-175, 1988.

Wallington, T. J., Skewes, L. M., Siegl, W. O., and Japar, S. M.: A relative rate study of the reaction of bromine atoms with a variety of organic compounds at 298 K, Int. J. Chem. Kinet., 21, 10691076, 1989.

Warneke, C., McKeen, S. A., de Gouw, J. A., Goldan, P. D., Kuster, W. C., Holloway, J. S., Williams, E. J., Lerner, B. M., Parrish, D. D., Trainer, M., Fehsenfeld, F. C., Kato, S., Atlas, E. L., Baker, A., and Blake, D. R.: Determination of urban volatile organic compound emission ratios and comparison with an emissions database, J. Geophys. Res.-Atmos., 112, D10S47, doi:10.1029/2006jd007930, 2007.

Warneke, C., Bahreini, R., Brioude, J., Brock, C. A., de Gouw, J. A., Fahey, D. W., Froyd, K. D., Holloway, J. S., Middlebrook, A., Miller, L., Montzka, S., Murphy, D. M., Peischl, J., Ryerson, T. B., Schwarz, J. P., Spackman, J. R., and Veres, P.: Biomass burning in Siberia and Kazakhstan as an important source for haze over the Alaskan Arctic in April 2008, Geophys. Res. Lett., 36, L02813, doi:10.1029/2008g1036194, 2009.

Warneke, C., Froyd, K. D., Brioude, J., Bahreini, R., Brock, C. A., Cozic, J., de Gouw, J. A., Fahey, D. W., Ferrare, R., Holloway, J. S., Middlebrook, A. M., Miller, L., Montzka, S., Schwarz, J. P., Sodemann, H., Spackman, J. R., and Stohl, A.: An important contribution to springtime Arctic aerosol from biomass burning in Russia, Geophys. Res. Lett., 37, L01801, doi:10.1029/2009g1041816, 2010.

Zhao, Z., Huskey, D. T., Nicovich, J. M., and Wine, P. H.: Temperature-dependent kinetics study of the gas-phase reactions of atomic chlorine with acetone, 2-butanone, and 3-pentanone, Int. J. Chem. Kinet., 40, 259-267, doi:10.1002/kin.20321, 2008. 